\title{
Distinction between the Concepts Mediation, Conciliation, Sulh and Arbitration in Sharīah Law
}

\author{
Essam A. Alsheikh* \\ Portsmouth University, Portsmouth, United Kingdom
}

\begin{abstract}
Nowadays, international trade with Islamic countries, specifically the Gulf States (GCC), is increasing and the Western World is beginning to show an interest in Islamic jurisprudence regarding commercial transactions, from which most rules on commercial laws in Islamic countries are derived. Such outside interest is associated with increasing calls from within Islamic countries in the Middle East for a return to Sharía law as source of jurisdiction in all aspects of life. The most significant of such calls concerns individuals, proprieties and trade. Arbitration is an alternative method of resolving commercial conflicts that is rapid and peaceful. Arbitration is one of the concepts in Islamic law which Western jurisprudence has tried to understand in the context of Islamic jurisdiction philosophy: e.g., how it was referenced in past books on jurisprudence and how it has developed in recent times as shown in modern writing. Arbitration can be intermixed with other contracts; for example, arbitration and the reconciliatory șulh contract are major concepts in Sharīa law that require study and profound analysis to distinguish clearly how Islamic scholars understand them and to eliminate what could cause confusion for non-Sharíah experts. This article explores the Sharīah notion of sulh and arbitration in theory and practice by demonstrating how these two contracts are applied in the Kingdom of Saudi Arabia, the country most likely to derive laws from the Sharíah at the present time.
\end{abstract}

\section{Keywords}

commercial law; arbitration; conciliation; mediation; șul contract; Sharîah; Saudi Arabia

* BA in Islamic Sharỉah Law (Honours), LLM (Distinction), and PhD, School of Law, Portsmouth University. Judge in the Ministry of Justice, Kingdom of Saudi Arabia. The author is very grateful to Professor Dr. (Munir) A.F.M. Maniruzzaman, his supervisor, who encouraged him to write and publish this article. The author would also like to send his sincere thanks to His Highness, Prince Dr. Bandar Bin Salman Bin Muhammad AlSaud, advisor of the Custodian of the Two Holy Mosques King Abdullah, Chief of the Saudi Arbitration Group, for his unrestricted support and encouragement. E-mail: ooa2002@hotmail.com. 


\section{General Introduction}

The Islamic Sharîa ${ }^{1}$ is based upon the attraction of interests and prevention of harm to human beings, ${ }^{2}$ i.e. the principle that everything of interest to human beings that does not cause harm is permissible (i.e. haläl), without regard to whether the thing is beneficial in whole or in part. ${ }^{3}$

Without doubt arbitration can prove beneficial to conflicting parties in that it can end conflicts rapidly with minimal costs. Moreover, arbitration is undertaken willingly by the conflicting parties as method to settle their dispute. Arbitration has been provided and recognized by the four sources of the Sharî'ah: the Qur'àn, the Sunnah (Prophetic tradition), ijma' (consensus of opinion) ${ }^{4}$ and qiyās (reasoning by analogy). ${ }^{5}$ As a means for resolving disputes according to certain rules and conditions, arbitration differs between Islamic Schools of jurisprudence. ${ }^{6}$ Over time, and through a succession of civilizations up to modern Western world, the notion of arbitration has developed greatly to become the preferred instrument for resolving international trade disputes and now considered superior to a traditional method in the Judiciary System. ${ }^{7}$ The legality of arbitration

1 "Sharîn ah is an Arabic word meaning the road to be followed. Literally it means 'the way to a watering place'. It is the path shown by Allāh, the Creator Himself, through His Messenger, the Prophet Muhammad." See Abd ar-Rahman I. Doi \& Abdassamad Clarke, Sharīah Islamic Law (London: Ta-Ha Publishers, 2008) p. 23.

2 See, e.g., F. Kutty "The Sharīah Factor in International Commercial Arbitration”, $L A$ Int'l \& Comp. L. Rev. 28 (2006): 566.

${ }^{3}$ Ibn Taymiyyah, Ahmad ibn 'Abd al-Halīm, Collections of Fatwā of Ibn Taymiyyah al-Hanbali, Vol. 11 (1985), pp. 344-345.

${ }^{4}$ In the technical sense, ijma is defined as: [t] he consensus of mujtabids (independent jurists) from the ummah of Muhammad (PBUH), after his death, in a determined period upon a rule of Islamic law (hukm sharīah). Nyazee, Imran Ahsan Khan, Islamic Jurisprudence (New Delhi: Adam Publishers, 2006) p. 183.

${ }^{5}$ In the technical sense, qiya $\bar{s}$ as defined by Islamic jurists applies to "the assignment of the hukm of an existing case found in the texts of the Qur'ān, the Sunnah, or ijma to a new case whose hukm is not found in these sources on the basis of a common underlying attribute called the 'illah of the hukm'. See Nyazee, supra note 4, p. 214.

${ }^{6}$ The majority of Muslims today hold to one of the four main Islamic Schools: Hanafi, Mālikī, Shāfíî, and Hanbalī. For more useful information, see, e.g., Doi \& Clarke, supra note 1, pp. 131-167.

${ }^{7}$ Mark A. Bunchanan, "Public Policy and International Commercial Arbitration", Am. Bus. Law J. 26(1988): 511-512. 
in the Sharī ah is derived from the Qur ān, ${ }^{8}$ the Sunnah ${ }^{9}$ and $i j m a^{{ }^{1} 10}$ and thus requires no further evidence. However, evidence for its legality can be derived from the following verse: Allāh commanded the people that when there is a problem between husband and wife to appoint two arbitratorsone from the family of the husband and one from the family of the wife. This text clearly makes arbitration between husband and wife permissible. If arbitration is permissible for resolving matrimonial conflicts, it should also be allowed for other conflicts by way of qiyās (reasoning by analogy), which is one source of the Sharīah. Philosophically, if the use of arbitration is permissible to bridge family - the prime nucleus of society-disputes, then it should also be permissible to resolve conflicts between members of society to avoid a rift in the social entity that is in the public's interest (al-maslahah al-mursalah). ${ }^{11}$ The term maslahah mursalah is applied when

8 The Holy Qurān contains verses from which Sharīah jurists derived the arbitration legality, such as, e.g.:

And if you fear a breach between the two, then appoint a judge from his people and a judge from her people; if the both desire agreement, Allāh will effect harmony between them, surely Allāh is Knowing, Aware. (Q3:35).

9 The legality of arbitration in the Sunnah is derived from the fact that Prophet Muhammad (PBUH) consented to arbitrate between Jews of Bani Gurizah when they requested him to do so. He appointed Sa ad ibn Mu'az to arbitrate and then recognized the award made by him and ordered it to be carried out. This became tangible evidence that arbitration is both permissible and legal. (See Abū Dāwud \& Sulaiman al-Sajestan̄i, Sunan Abì Dāwud, quested by Muhammad Mohiedeen Abdulhameed, Dār al-Fikr for Publishing and Distribution, Vol. 4, p. 289, Hadith 4955. See also Al-Nisaee, Ahmad bin Shuwaib, Al-Sunnah al-Kubrā, reviewed by Abdulgafar Al-Bandari, and Syid, Vol. 3, p. 466, Hadīth 5940/1, corrected by Al-Albanī, Erwa al-Ghaleel al-Albanī (Beirut: Al-Maktab al-Islāmī, 1979) Vol. 8, p. 237.

${ }^{10}$ Sharīah jurists differ in opinion regarding the matter of arbitration and its permissibility. They fall within one of three opinions. The first opinion is that arbitration is totally permissible, whether or not there is a judge in the city. This opinion is held by the four main jurisprudence schools: Hanafī, Mālikī, Shāfíi and Hanbalī, plus Ziadī and some Shỉa. They rely upon texts from the Qur'ān, the Sunnah, ijma' and qiyās, in each of which arbitration is mentioned. The second opinion holds that arbitration is permissible, provided that there is no judge in the city.

${ }_{11}$ Al-maslahah al-mursalah, sometimes referred to in the plural as al-maslahah al-mursalah, is a highly flexible and advanced type of analogy. It is employed when jurists cannot find a rule for the case at hand through literal interpretation or strict analogy (qiy $\bar{s}$ ), because there is no specific base (asl) from which he can extend the rule by analogy. In other words, neither individual nor specific evidence controls the law. See Nyazee, supra note 4, p. 241. 
an issue is not referred to in Qur ānic text. ${ }^{12}$ In other words, we turn to the concept 'public interest' when we lack supportive Qur'ānic text, provided that no other text contradicts the issue that one is trying to prove. Doi and Clarke stated that:

It should be noted that the concept of public welfare and general interest can really be very helpful particularly in cases which are not regulated by any authoritative text of Book of Allahh, the Sunnah or ijma. In that case, equitable consideration may override the results of strict qiyās, taking public interest into consideration. ${ }^{13}$

It is noteworthy that the connotation of 'muslahah' in Arabic differs completely from the meaning of al-maslahah al-mursalah in the Sharíah. For this reason, arbitration falls under the linguistic meaning of muslah $h$ a and not under the notion of al-maslahah al-mursalah in the Shari'ah. This is commonly misunderstood by researchers who try to understand arbitration through the notion of maslahah mursalah, where the legal and linguistic connotations can create confusion. This is the opinion of some scholars from the Shäfi i School, based on their belief that arbitration is second to judicature and that a judge is the principal arbiter of conflicts. Hence, some Shāfi i jurists believe that arbitration is not permissible while a judge is present. Contrary to this opinion, however, it can be stated that an arbitrator serves in place of a judge, helping him to resolve the conflict. Further, since it is not explicitly forbidden in the Sharîah, arbitration remains permissible because the original judgment on issues, contracts, and transactions is permissible unless a specific text renders it otherwise. A third opinion held by a number of Shāfíi jurists, and Al-Khawārij, who opine that arbitration is never permissible, based on the fact that conflict resolution is the basic function of the Great Imām and anyone to whom he delegates this authority. Hence, arbitration is an assault upon the authority of the Imām, his deputies and judges. However, this opinion can also be challenged on the basis that arbitration does not invade the Imam's authority because the arbitrator has no authority to imprison or to implement a judgment. The arbitrator may only resolve conflicts based upon justice and reasonability, which Islam does not prohibit. ${ }^{14}$

12 Al-Jizani, Muhammad bin Hussain, Ma'lim Usül al-Fiqh 'an Abl al-Sunnah wa Ijmä', 7th edn. (Riyadh: Dār Ibn al-Jawzī, 2007), p. 236.

13 Doi \& Clarke, supra note 1, p. 125.

${ }^{14}$ Ibn Najeem, Zain Aldeen Ibn Ibraheem, Al-Bahr al-Rảiq, Vol. 7, (Beirut: Dār al-Mārifah) p. 42. Al-Ramli, Nihayat al-Muhtaj, Vol. 8, p. 230. Al-Kharshi, Muhammad 


\section{Concept and Types of Reconciliation: Sulth in the Sharîah}

The concept 'reconciliation', sulh in the Sharîah, means a contract that is concluded by two parties, under which each party waives part of his rights for the purpose of reaching a mutual and final resolution of a conflict. ${ }^{15} \mathrm{To}$ illustrate, suppose that someone claims that he is owed $£ 1,000,000$, although he has no evidence to prove his claim. In contrast, the defendant agrees that he owes the plaintiff money, but not in excess of $£ 700,000$. The plaintiff could settle the dispute by agreeing with the defendant to accept payment of $£ 700,000$, provided that the payment is final and complete and that their conflict will end upon payment of the agreed amount of money. This type of reconciliatory contract is just as common today as it was in the past. Sharīah jurists ( $f a q i \bar{h}$, pl. fuqah $\vec{a}$ ) mention in their legal writings that conflicting parties conclude a contract of reconciliation to be authenticated by a judge ending the conflict between them. The jurists insisted that the judge has no power to compel the parties to conclude by reconciliation in the event that one or both parties refuses. On this point in particular, the similarity between reconciliation and arbitration contracts is apparent in that each type of contract is considered a supplementary manner to resolve conflict. Because these contracts are optional, the judge has no power to compel conflicting parties to enter such a contract. Only if the parties agree to such a contract will the judge have the power to order the parties to enter the contract and end the conflict. The same situation occurs if the parties have agreed in advance to solve their conflict through arbitration or to conclude an arbitration agreement. The judge will compel the parties to arbitrate in accordance with their agreement. Such issues fall under the general theory of contracts in the Sharíah, ${ }^{16}$ which requests that people adhere to contracts they conclude and remember that steadfastness to ones deeds comes under the philosophy of faith,

bin Abdullah, Sharh al-Kharshī, Vol. 7 (Beirut: Dār Sadr) p. 145. Ibn Rushd, Muhammad bin Ahmad, Bidayat al-Mujtahid, Vol. 2 (Beirut: Dār Al-Fikr), p. 452. Ibn Gudamah, Abdullah bin Ahmad, Al-Mughni, Vol. 11 (Beirut: Dār al-Kitāb al-'Arabī) p. 483. AlMardawi, Alī bin Suliman, Al-Insaf, Vol. 2 (Beirut: Dār Ihya' al-Turath al-'Arabī), p. 197. Al-Murtada, Ahmad bin Yahya, Al-Bahr al-Zakhar, 2nd edn., Vol. 6 (Beirut: Al-Risalah) pp. 113-114. Al-Amili, Muhammad al-Jawad, Muftah al-Karama, Vol. 10 (Damascus) p. 3.

15 Al-Zailaie, Othman ibn Alī, Tabyīn al-Haqā̇iq Shar'h Kanzu ad-Daqǟiq, 2nd edn., Vol. 5 (Beirut: Dār al-Mārifah) p. 29. Ibn Qudamah, Abdellah ibn Aḥmed, Al-Mughni, Vol. 4 (Beirut: Dār al-Kitāb) p. 476.

16 Sürah Al-Mä̀idah, Q5:1. 
which every Muslim must in any event follow in his/her commercial transactions and marriage affairs toward both Muslims and non-Muslims alike.

The idea discussed above, which is only one form of a reconciliation contract under the Sharíah, is referred to as 'reconciliation in the case of denial by the defendant'. This form of reconciliation is permissible in the opinion of Hanafīi, ${ }^{17}$ Mālikīi, ${ }^{18}$ and Hanbalīi, ${ }^{19}$ but not Shāfi ${ }_{1}{ }^{20}$ jurists. In such a case, the defendant denies the debt or immovable thing that the plaintiff claims while admitting that the plaintiff has a right to less than what he is claiming. Accordingly, admission and denial occur simultaneously. The majority of Islamic jurists share the opinion that the notion of sulh is permissible according to the Qura ân, the Sunnah, ${ }^{21}$ and $i j m a$. Under such circumstances, there is nothing to prevent the conflicting parties from drawing up a sulh contract to end their conflict. On the other hand, Shäfi ì jurists opine that, in such cases, sulb is not permissible by asserting that, in the event of a defendant's denial, sulh falls under Prophet Muhammad's (PBUH) directive not to make sulh, which makes ill-gotten things permissible in Islam. Further, a defendant's act of paying money solely for the sake of ending the conflict is similar to the act of giving a bribe, which is not permissible in Islam. In fact, this reasoning is invalid because sulh, which is not permissible according to the above-mentioned Hadith, is the form in which sulh is a tool to make permissible a thing that is ill-gotten in everyone's opinion. An example would be if the plaintiff were to give the defendant wine or pork to end their conflict. It could be said that this form of sulh is inapplicable here because the defendant is agreeing to pay money or requital as the case may be to avoid responsibility and end the conflict, thereby saving himself from banality and protecting his name and self from becoming vulnerable to judicial authority. The Sharî́ah does not

17 Al-Zailaie, supra note 15.

${ }^{18}$ Ibn Rush, Muhammad ibn Ahmad, Bidayat al-Mujtahid wa Nihayat al-Muqtasid, Vol. 2 (Beirut: Dār al-Fikr) p. 290.

${ }^{19}$ Ibn Qudamah, supra note 15.

${ }^{20}$ Al-Shirbini, Muhammad al-Khateeb, Mughni al-Muhtaj' alā Marifat mánī al-Minhaj (Cairo: Mustafa al-Babī al-Halabī Printing Press, 1985) p. 179 et seq.

${ }^{21}$ Allāh the Almighty said: ([m]aking peace is better), Sürah An-Nisä, Q4:128. Prophet Muhammad (PBUH) said that sulh is permissible between Muslims, except when it makes ill-gotten things permissible or vice versa. This Hadith has been proven correct; see Ibn Hajar, Aḥmad ibn Alī ibn Muhammad, Al-Talkhìs al-Habì fì Takhrīj Aḥadìth al-Rafì al-Kabir (Cairo: Ibn Taymiyyah Printing Press), p. 249. 
prevent a person from keeping himself safe and out of harm's way, even incorporeal harm, by offering money. On the other hand, the plaintiff is taking money from the defendant as compensation for his assured right. Hence, the Sharīah does not prevent him from doing so. This is the philosophy supporting judicial opinions claiming that this form of sult contract is permissible in the Sharīah. On this basis, such jurists maintain that jurisprudence identifies ${ }^{22}$ this form of sulh contract as having a compensatory nature: the plaintiff perceives receipt of money as compensation of his right while the defendant perceives the contract as a tool to avoid taking an 'oath' before the judge. Hence the Sharīah rules that: "evidence is required of a claimant and an oath is required of someone who denies [the claim]". ${ }^{23}$ Another form mentioned by jurists is to make sulh with a defendant who has admitted the right. Here the defendant admits the plaintiff's claim, while agreeing to pay a certain amount of money or offering something in return for settling the debt and ending the conflict. As illustration, assume that someone claims that another individual borrowed $£ 100,000$ in 2007, although he has no supporting evidence. If the defendant nevertheless admits his debt and offers to give the plaintiff an apartment in satisfaction of the debt, the conflict is ended with sulh, which will be classified according to the most similar contract. In this example, sulb will take the form of a sales contract. Because the apartment is given against the debt, sulh follows all the rules of a contract of sale, such as emergence of the right of pre-emption for neighbours if the payment is land instead of real estate. Similarly, because the plaintiff acquires the right to return a defective thing, he could reject an inferior apartment if its value is insufficient. Moreover, the price must be known and determinant for the sulh contract to be valid, similar to the case of a sales contract.

Another form of sulh involves a defendant who neither admits nor denies but rather agrees to give a thing or pay a certain amount of money to the plaintiff for the sake of ending their conflict. This form of sulth is considered permissible by the majority of jurists. However, Shāfi î jurists, who forbid it, ${ }^{24}$ argue that the defendant's silence should be interpreted as

22 Ibn Rushd, supra note 14.

${ }^{23}$ Al-Bukharī, Muhammad Ibn Ismail, Sahih al-Bukharī, 3rd edn., reviewed by Dr. Mustafa Deeb Al-Bagha (Beirut: Dār Ibn Khathīr, 1987). Hadīth No. 4187, Al-Qasheeri, Muslim ibn al-Hajjaj (Beirut: Dār Ihya' al-Turath), Sahih al-Muslim, reviewed by Muhammad Fuwad Abdelbaqi, Hadīth No. 3228, see also in general Doi \& Clarke, supra note 1, pp. 36-37.

${ }^{24}$ Al-Shirbini, supra note 20. 
a denial of the case, consequently making sulh neither permissible nor achievable. Contrary to this position, it could be argued that the defendant's silence can be interpreted in many ways. For example, he could be hesitant and unsure about the claim, yet at the same time wish to exonerate himself before Allāh by reconciling with the plaintiff to pay a certain amount of money or to give a specific thing to end their conflict. It is worth mentioning that, in Sharíah law, jurisprudential applications, ethi$\mathrm{cal}$ and religious values are assimilated in the fear of punishment by an individual in the Hereafter and are mixed with materialistic values built on material evidence in procedural claims and commercial transactions. As a result, an individual could forfeit material gain for the merit of sustaining peace of mind between himself and Allāh. The best achievement would be to disperse the culture of sulh among members of society as a means to resolve conflict and to erase hatred from human hearts, i.e. in essence the effect which the Sharîa strives for through its values and directives.

Part of the similarity between sulh and arbitration contracts are the conditions that must be available to the party concluding the contract. For example, the person who concludes sulh must be sane, because both the insane and minors ${ }^{25}$ have no eligibility. Moreover, sulh must not disfavour a minor if it is to be performed by his custodian. Just as in arbitration, if one of the parties to the arbitration is a minor, the custodian must make certain that sulh or arbitration does not disfavour the minor; otherwise the contract will be invalid.

The subject ${ }^{26}$ of sulh contracts must be treasury (of financial value), or something similar such as real estate, owned by the defendant and known to the parties. Jurists list important types of dispute that could occur between people today, and upon which sulh may be applied, although not purely permitted by the Sharíah as subject of sulh, at least in the opinions of some jurists. The three most significant situations are the following.

In the first situation, debt is deferred, and the debtor and creditor are reconciled that part is to be paid in advance while the remainder is waived. For example, say a $£ 1,000$ debt is to be paid after 1 year, and the creditor reconciles with the debtor to accept $£ 800$ now on condition that the remaining $£ 200$ will be waived. This form of sulb is not permissible in the

\footnotetext{
25 "A minor (someone who has not reached the age of puberty)"; see Doi \& Clarke, supra note 1, p. 553.

${ }^{26}$ The subject matter in this instance is the price paid by the defendant to the plaintiff to end their conflict.
} 
opinion of most jurists because in this case the sult contract becomes a compensation contract, for which the price is delay in payment. Since delay is not of a financial nature $(m \bar{a} l),{ }^{27}$ it cannot be equated with price in a sulh contract. Such jurists find some similarities between credit usury $(r i b \bar{a})^{28}$ and this type of sulh. They also see delay in payment as vital to addition in credit usury and vital to diminution in this form of sulh. Ibn al-Qiyyam ${ }^{29}$ has discussed this opinion. He and his teacher, Ibn Taymiyyah, ${ }^{30}$ are of the opinion that this form of sulth is permissible. They reason that this form of sulth is ultimately counter to usury, because usury includes an addition in one of the payments as the price of delay. Hence, in this type of sulh, part of the price is waivered instead of making an advanced payment. Both parties benefit such action; there is no question of usury which is an addition, which is absent in this case. Ibn al-Qiyyam's reasoning is upright and logical in that both parties obtain benefits, but without usury. Accordingly, this falls within what is permissible which rests upon the consent of both parties, by one party waiving some of his rights to benefit in return for being paid in advance by the other party.

In the second situation, debt is immediate, and the plaintiff reconciles with the defendant to pay part of the debt within a certain time. As illustration, suppose that the debt is $£ 100,000$ pounds. The plaintiff agrees with the defendant to pay only $£ 90,000$ in full satisfaction of the debt, but he fixes a time for the payment to be made on Friday. If the defendant fails to pay on Friday is he then liable to pay the $£ 90,000$ or $£ 100,000$ ? Jurists are of two opinions on this question. Abū Hanifah and his student, Muhammad ibn al-Hassan, said that, if the payment is not made on Friday, the debt will return to its original status, and sulh will be nullified because the defendant did not adhere to the plaintiff's stipulation. Abū Yusuf, who is also a student of Abū Hanifah, argues that the sulh contract includes suspension in that part of the debt is being waived upon the condition that payment is actually made. He contends, however, that waiving

27 " $M a \bar{l} l$ is something that exists and can be held in use and be beneficial at the time of need"; see Doi \& Clarke, supra note 1, p. 551.

${ }^{28} R i b \bar{a}$ is basically any amount of interest on capital loan; see Coulson, N.J., A History of Islamic Law (Edinburgh: Edinburgh University Press, 1995) p. 239.

${ }^{29}$ Ibn al-Qiyyam, Muhammad Ibn Abī Bakr, 'alam al-Muwaqin 'an Rabb al-'Alamina, Vol. 3 (Al-Sädah Printing), p. 371. It is worth mentioning that this opinion is said to be that of Imām Aḥmad Ibn Hanbal (Allāh's mercy be upon him).

${ }_{30} \mathrm{Al}$-Ba'ali, Muhammad bin Abbas, Al-Ikhtiyarat al-Ilmiyyah min Futawä' Ibn Taymiyyah (Cairo: Dār al-Kutub al-'Ilmiyyah, 2000), p. 134. 
cannot be suspended on conditions. Hence, if the plaintiff does not intend the defeasance of the contract, if the defendant does not fulfil his condition, then the sulh contract remains valid, and the defendant is liable to pay only the agreed amount. Logically, Abū Hanifah's opinion is more viable and practical, because it must be concluded from his having suspended the waiving of his right on a condition and a specific time that the plaintiff suspended the contract defeasance on those terms. Otherwise, the condition would be without value. Moreover, following Abū Yusuf's opinion would render the possibility that such sulh contracts would be impossible, for it would endanger the plaintiff should the defendant fail to adhere to the condition, in which case the underlying claim would remain in full force. This would particularly be the case if the defendant realized that he benefited from the sulh contract immediately after entering into it, for part of the debt has been waived and his obligation to pay within the specific timeframe or not at all, will not affect that waiver. The plaintiff who proposed the sulh contract is supposed to be the most powerful party but he will become the weaker party, which is not permissible. The plaintiff should remain the strong party while the defendant's role is to adhere to the conditions stipulated if the contract is to be of value for both, and not just one, parties. This is the philosophy intended by a sulh contract in the Sharíah.

The third situation occurs when the conflicting parties agree to reconcile and the price offered is a benefit rather than a tangible thing or money. In other words, the defendant, who owes the plaintiff $£ 10,000$ pounds, agrees to give the plaintiff use of his apartment for 1 month in an area popular among tourists in lieu of paying the amount owed in funds. In this case, jurists say that the sulh contract is permissible, in that it resembles a rental contract. ${ }^{31}$ As stated earlier, a sulh contract assumes the form of the most similar contract. Hanafi jurisprudence is distinct from the three other schools in that it deals with many hypothetical cases, some of which occurred in past eras and others in modern times. No doubt the existence of solutions for hypothetical cases gives evidence of the richness of the Hanafi School, of which we are badly in need nowadays. This is especially so in light of many emerging issues and new commercial transactions that require intelligence and the ability to study new contracts and issue jurisprudential solutions that are suitable, effective, flexible and do not collide

31 Al-Kasani, Alaoldeen Abū Bakr, Badayī al-Sanayī fì Tartīb al-Sharīáah, Vol. 6 (The Scientific Publications Co.), p. 47. See also Ibn Qudamah, supra note 15, p. 483. 
with common Sharīah rules. Hence, we should do away with stagnancy in jurisprudence, which agitates unreal doubt about Sharīah's capability to escort new issues into all the modern fields of human inquiry.

\section{Similarities between Șulh and Arbitration from an Islamic Point of View}

\subsection{Mutual Consideration between Parties}

Similar to all other contracts, sulh and arbitration are based upon the mutual free will of the parties, who draw up a binding contract, as long as the contract has been concluded free of any intentional flaws or reasons for annulment. That two contesting parties seek alternative methods of conflict resolution is urgently needed and sign of healthy behaviour in a humanitarian society. Parties are prompted to seek alternative means of resolution out of the intention latent in every human being to main peaceful co-existence, harmony and reconciliation, which in turn manifests itself in the form of legal actions.

\subsection{The Contract Is Binding Upon All Parties}

Sulh is a contract that binds both consenting parties from the time of its conclusion. Arbitration differs as will be explained later. In the Sharīah, the principal rule with regard to an arbitration contract is that the contract is binding upon both parties once the arbitration begins. ${ }^{32}$ The judge takes the responsibility of executing sulh, or the arbitration contract, in case one or both parties needs judicial intervention. Al-Ramahi says that the sulh contract is not binding unless it is concluded before the judge. She points out: " $t \mathrm{t}$ he agreement of such is not binding unless it has taken place before the court." 33

This notion is non-admissible for a sulh contract which is binding upon both parties from the time of its conclusion. Here all legal effects fall upon the contracting parties. When a conflict over the terms in the contract arises, or when one party refuses to adhere to the contract, the judge may

\footnotetext{
${ }^{32}$ Ad-Dirdir, Asharh as-Saghìr, Vol. 2 (Essa al-Halabi Publications, 1976), p. 516.

33 Al-Ramahi, A. (2008) Șulh: A Crucial Part of Islamic Arbitration, Islamic Law and Law of the Muslim World, Research Paper Series at New York Law School, No. 08-45, p. 12.
} 
compel the repudiating party to fulfil his obligations under the sulh contract. The Shari ${ }^{-1}$ ah advocates adherence to contracts in accordance with many Qur'ānic or Sunnah texts, as mentioned earlier..$^{34}$ Moreover, under the Sharīah, arbitration and sulh contracts are not nullified by the death of the one of the parties but instead bind the inheritors by the conditions of these contracts.

\subsection{The Substantive Scope}

The similarity between arbitration and sulh contracts appears on a subjective level, for in the Shari ah the scope for arbitration is the same as that for sulh. ${ }^{35}$ In other words, all matters that can be subject to sulh can be subject to arbitration. It may be suitable not to explain the scope of sulh in detail here, but only to state briefly that, to be valid, a sult contract must fall within the rights of the human being, not Allāh, hudiud, or tazìr, ${ }^{36}$ because the rights of a human being can be waived and not the rights of Allāh.

\subsection{The Benefit}

Sulh and arbitration ${ }^{37}$ share the fact that each results in resolving disputes between parties. After a sulh contract is concluded, it is binding upon both parties ${ }^{38}$ such that it is not permissible for one party to refuse the contract or to claim the same thing or right before the court. Similarly, Hanafí, Mālikī, Shāfíî, and Hanbalì scholars are of the same opinion that arbitration is binding upon both parties once it has been declared by the arbitrator as ending a conflict. Arbitration differs from sulh in that its contract can be concluded before or after the disputes occurs, whereas a sulh contract is normally concluded after a conflict arises. ${ }^{39}$

\footnotetext{
${ }^{34}$ See supra note 14.

${ }^{35}$ Al-Mawirdi, Adab al-Qadī, 4th edn., Vol. 2 (Baghdad: Dār Ihya' al-Turath al-Islāmī, 1972) p. 380.

${ }^{36}$ Al-Zailaie, supra note 15, p. 37.

${ }^{37}$ See, e.g., Doi \& Clarke, supra note 1, p. 576.

38 Al-Sarakhsi, Muhammad ibn Aḥmed, 2nd edn., Al-Mabsut, Vol. 20 (Cairo: Dār al-Mārifah) p. 163.

39 Al-Ramahi, supra note 33, p. 12.
} 


\subsection{The Obligation Ended by Contract between the Parties}

If we scrutinize the opinions of jurists for conditions that can nullify a sulh contract, and in turn end the obligations upon the contracting parties, we will find similarities between sulh and arbitration, manifested as follows:

(A) Jurists name the agreement between contracting parities to end the obligation and consider the contract null and void as discharge ${ }^{40}$ or "al-iqälab" in the context of a sulh, which is called arbitrator dismissal in arbitration..$^{41}$

(B) Absence of eligibility on part of the contract of both ${ }^{42}$ parties, facing it eligibility of arbitrator ${ }^{43}$ or one of the conflicting parties before the issuance of the arbitration award.

Jurists have stated that the death of one party to a sulh contract, in which payment is a benefit and not money or real estate, renders the contract of sulh void if death occurred before the end of the agreed period of time determined by the parties, during which the benefit is supposed to be acquired by the beneficiary party. The same is not the case for an arbitration contract, for which jurists did not declare that death of one of the arbitrating parties renders the arbitration contract null and void. El-Ahdab ${ }^{44}$ errs when he finds that the death of one party to an arbitration contract nullifies the contract. This might indicate that the death of one contracting party does not affect the arbitration contract that remains binding upon the inheritors upon the results of arbitration and, most importantly, the arbitration award.

\subsection{Judges May Suggest that Both Disputing Parties Choose Either} Reconciliation or Arbitration as Alternative Means to Resolve the Conflict

This point is confirmed by practical applications. For example, in the Kingdom of Saudi Arabia, in some cases judges frequently offer arbitration if the conflicting parties wish to quickly resolve their conflict. The same

40 Al-Zailaie, supra note 15, pp. 32-34.

${ }^{41}$ Al-Girafi, Ahmad bin Edrees, Al-Furūq, Vol. 4 (Beirut: Dār al-Mārifah), p. 13.

42 Al-Kasani, supra note 31, p. 54.

43 Al-Fatawä al-Hindiyyah, narrated by a group of Indian Scholars from the Hanafi School in the 11th century Hijrah (17th century CE).

${ }^{44}$ Abdul Hamid El-Ahdab, The Arbitration Encyclopedia, Vol. 1 (Cairo: Dār al-Mārifah) p. 49. 
applies to reconciliation which judges frequently offer in court to resolve conflicts amicably, rather than through judicial judgment. This will be discussed in more detail in Section 4, below.

\section{How Do Mediation, Conciliation and Reconciliatory Sulb Differ from an Islamic Perspective?}

In fact, if we scrutinize the writings of Islamic jurists, we will not find citations on mediation as a means of conflict resolution. In contrast, jurists have studied the sulh contract in detail without differentiating between sulh, on one hand, and mediation and conciliation, on the other hand. This might possibly be due to the fact that mediation, like conciliation but unlike sult and arbitration, is a voluntary means provided by an individual in society without having any obligatory effect on the conflicting parties and a third party. This philosophy may explain why jurisprudence neglects to mention mediation as a tool to achieve sult from a third party. Practice confirms the existence of mediation in some cases during Islamic history, e.g. when Abdullah Ibn al-Abbas (blessings of Allāh upon him) was sent by Caliph Alĩ Ibn Abī Taalib (blessings of Allāh upon him) to the Khawārij ${ }^{45}$ to convince them to arbitrate, according to the famous story. ${ }^{46}$ Considering what has already been said and studying the general rules of the Sharīah, we will find a rich source supporting mediation as a moral and peaceful alternative undertaken by upright individuals in a society motivated by purely humanitarian principles to resolve differences between people. In modern times, which has become very complicated, paid efforts to mediate can be excused, for mediation requires time and effort and may prove costly for individuals involved. However, the ethical and religious

45 The Khawārij was a political group that arose at the time of Caliph Alī Ibn Abī Tāalib due to political differences at that time. Caliph Ali battled with them and defeated them at Nahrawan. Their numbers were 2,000, while Alī's men numbered 70,000. This group disobeyed the orders of Alì Ibn Abì Țālib and refused arbitration of the issue between Alī and Moawiyah, (May Allāh Bless them all). They had their reasons and justifications that had been discussed together them Abdullah Ibn Abbas, who had been sent as a mediator. He was able to convince a large group of them, although a few segments refused his opinions and mediation. See Al-Shahristani, Muhammad ibn Abdulkareem, Al-Millal wa l-Nihall, reviewed by Abdulaziz Muhammad al-Wakeel, the Editor is Mostafa al-Halabi, p. 114).

${ }^{46}$ See Al-Bayhaqi, Ahmad ibn al-Hussain, Sunan al-Bayhaqī, Vol. 8 (Cairo: Dār alFiqr), p. 178. 
aspects of mediation take priority. The Sunnah tells us that Prophet Muhammad (PBUH) said the following to his companions:

May I tell you of a work better than praying, fasting, and charity, they replied by saying, yes messenger of Allāh. He said, that is to mediate between those who had a conflict between them. ${ }^{47}$

This Hadith is considered to be a tangible proof for the permissibility of mediation under the Sharīah in that Prophet Muhammad (PBUH) ranked it superior to praying, fasting, and charity. This indicates the significance of mediation as a method to sustain peace and harmony between members of society, be they Muslims or non-Muslims. It is worth mentioning that the jargon of conciliation is used in the West, referring to mediation efforts undertaken by a third party to redress a dispute between conflicting parties under specific procedures. This classification is unknown in Sharíah law, in which there is no difference between conciliation and mediation, although there are general texts that compliment the work of mediators, conciliators, and reconciliators as individuals working toward the redress of problems between conflicting parties whether in commercial transactions or family affairs, with no distinct difference between these alternative methods of conflict resolution.

\section{Concept of Arbitration in Islam: Is it Conciliation, Sulh or Justice?}

After explaining the concept sulb in the Sharīah, we turn to a very significant issue that is the admixture of legal and linguistic concepts of sulh and its effect on the identification of arbitration as sulh from the point of view of the Sharíah. It might be acceptable to identify arbitration as a type of conciliation and reconciliation in the general linguistic meaning of the consideration that arbitration is not binding, at least in the opinion of one segment of Sharîah jurists. However, it is fruitful to abide with jurisprudential terminology, which sometimes give more specific meaning than the general linguistic connotations and which has consequential legal effects. We will discuss this matter from various perspectives as follows.

${ }^{47}$ Abū Dāwud, Sulaiman ibn al-Asha'ath, Sunan Abì Dāwud, Hadīth 4273, and the Hadīth is corrected as per Al-Albani, Muhammad Nasiro Eldeen, Series of Correct Hadith, Vol. 6, p. 141, Hadith 2639. 


\subsection{The Need to Differentiate Arbitration between Spouses and Other Arbitrations}

Arbitration between spouses is a form of arbitration under Sharīah law, ${ }^{48}$ which normally comes to mind when speaking about arbitration as a legal term. This may be due to the excessive judicial usage of this term in past and present times, which makes individuals who are not Sharīa ah experts understand that this kind of arbitration is the only one available under Sharîa law. This kind of arbitration is also confused with general arbitration, when vital differences between the two forms go unnoticed. Among those who made this mixture are El-Ahdab ${ }^{49}$ and George Sayen. ${ }^{50}$ If we return to veracity of arbitration in the case of conflicts between spouses, we will find that jurists hold different opinions with regard to the role of the arbitrator. The majority of jurists ${ }^{51}$ are of the opinion that an arbitrator's award is binding upon the spouses regardless of whether they are considered arbitrators or agents of the spouses, as stated by Ibn Taymiyyah. Despite this, the practice in Saudi Arabia, ${ }^{52}$ for example, follows the opinion of the majority of jurists, which binds the judge with what arbitrators have determined, unless the award infringes upon the Sharîah. Another opinion that considers arbitration between spouses by a third party as part of sulh and non-binding is held by Ibn $\mathrm{Hazm}^{53}$ (d. 456H) and Ibn Taymiy$\operatorname{yah}^{54}(\mathrm{~d} .728 \mathrm{H})$, and is one of the Máliki opinions. ${ }^{55}$ This opinion is based upon the consideration that such arbitration is reconciliatory, and that the mediator ought to resolve the conflict informally. This might be

${ }^{48}$ Gamal Eldin Attia stated that: (In this context, the spouses follow an approach laid out by Islamic law for arbitration in the event of a dispute between them and for severing the marital bond if the dispute becomes insoluble). See Attia, Gamal Eldin, (April 2008, International Islamic Institute), Towards Realization of the Higher Intents of Islamic Law: Maqasid al-Sharīah: A Functional Approach, p. 130.

${ }^{49}$ El-Ahdab, supra note 44, pp. 25-27.

${ }^{50}$ George Sayen, "Arbitration, Conciliation, and the Islamic Legal Traditional in Saudi Arabia”, J. Int'l Econ. Law 24 (Winter 2003): 944-945.

${ }^{51}$ Ibn Taymiyyah, supra note 3, p. 386.

52 The judgment issued by the General Court in Riyadh on 15 November 2003, and also the judgment issued by the same court in November, 2004, both judgments issued by Judge H.A. Abdulaziz.

53 Ibn Hazm, Alī ibn Aḥmad, Al-Huhala, Vol. 10, p. 87.

${ }_{54}$ Al-Ba ali, supra note 30, p. 250.

55 Al-Zargani, Abdul Baqi, Sharh al-Zarqani alā Mukhtasar Khalīl, Vol. 4 (Beirut: Dār al-Fiqr) p. 62. 
the meaning intended in Qur'ānic texts, in light of Allāh's words regarding arbitrators in spousal arbitration which can be translated as follows:

And if ye fear a breach between them twain (the man and wife), appoint an arbiter from his folk and arbiter from her folk. If they desire amendment Allāh will make them of one mind. Lo! Allāh is Ever Knowing, Aware. ${ }^{56}$

The Almighty uses the expression of amendment with regard to vanishing evil between spouses, which is left to the choice of the spouses. ${ }^{57}$ This stands as evidence that reconciliators and arbitrators are just mediators. In fact, the opinion of the majority of jurists does not support arbitration as just a form of mediation from the viewpoint of the Shari'ah, because it is binding upon the spouses, as well as the judge, to follow the award of the arbitrators.

\subsection{Third Party in Arbitration}

Arbitration, as another means of settling dispute (i.e., conciliation and mediation), ${ }^{58}$ differs from sulh in that it is performed by a third party. The third party in arbitration is the arbitrator(s) selected by the parties. ${ }^{59}$ Sometimes the judge appoints the arbitrator. Islamic scholars require specifically that the arbitrator must be a Muslim, ${ }^{60}$ an adult, and sane. Scholars argue

56 The Holy Qur'àn, Sürah An-Nisä’’, Q4:35.

${ }^{57}$ See, in general, Doi \& Clarke, supra note 1, p. 217.

58 See, e.g., M. Hunter, The Freshfields Guide to Arbitration and ADR; Clauses in International Contract (Deventer: Kluwer Law \& Taxation Publishers, 1993) p. 65.

59 Y. Al-Samaan, The Legal Protection of Foreign Investment in the Kingdom of Saudi Arabia, 1st edn. (Dār al-Andalus for Publ. \& Dist., 2000) p. 255.

${ }^{60}$ From my own point of view, the requirement that the arbitrator be Muslim is subject to review, especially if we consider the rules of international arbitration and economic and commercial relations between countries around the world. It is not logical to make this condition an evaluation criterion for the efficiency of the arbitrator. In addition, since the function of the arbitrator is similar to that of the judge, we require the arbitrator to comply with all of the conditions required of the judge. Many arbitrators and international arbitration centers are directed by non-Muslims. Therefore, if we abide by this condition, we will forfeit the opportunity to benefit from others and create artificial barriers that will preclude us from commercial and arbitral connections with other countries, particularly in the Western World. It could be said, however, that, if an arbitration is in one of the Islamic countries and the parties request the application of the Sharíah rules and principles on the subject of the dispute, a non-Muslim arbitrator must have a deep understanding of Sharî́ah rules and principles. In addition, there is no evidence from the Qur'ān, Sunnah or ijma requiring that an arbitrator be Muslim. This condition was opined by scholars from the 
on other conditions, such as soundness, male gender, and accuracy of the senses.

\subsection{Arbitration Enforcement}

Under the Sharîah, arbitration is unlike conciliation, which is not obligatory. The four major Islamic Schools agree that, when an arbitration award is issued, it will be obligatory for both parties. Neither party will have the right to retreat, provided that the award is not contrary to the Shari ah. The obligatory nature of arbitration is manifested in what has been said by the majority of jurists. Hence, it is not accurate to say, as some researchers have, that the Sharîa is unclear about the obligatory nature of arbitration for the parties. For example, Faisal Kutty states that "There is no clear position on this question in any of the four leading Sunni schools." 61

Disagreement in the Shari'ah regards the extent to which arbitration obligates the parties after commencement of proceedings and before issuance of the award. The legal arguments in figh appear in highlighted opinions of some Sharîah scholars that say that the arbitration agreement is not binding upon either party. This argument can be avoided by adopting another fiqh opinion, ${ }^{62}$ which says that the arbitration agreement obligates all parties after commencement of the arbitration proceedings, from which time no party has the right to withdraw. This opinion was reached by the Islamic Fiqh Academy in its Decision No. $91(8 / 9)^{63}$ and conforms to Sharīah intention, which calls for the respect of contracts and its obligation for both contracting parties. This coincides with modern arbitration

past, while the general rules and sources of the Sharîa authorize judicial and commercial dealings with non-Muslims. Applying this condition reflects a critical position and an unnecessary contraction. The principles of Sharíah law accompany tolerance, brotherhood, justice and the facilitation and the lifting of the critical issues. This idea was supported by the General Muftī of the Kingdom of Saudi Arabia, and the Chairman of the Senior Scholars Commission views that a non-Muslim may be an arbitrator and member of the arbitral tribunal provided that he is aware of the general principles and concepts of the Sharíah. (The author (Essam) had an interview with the Saudi Grand Muftī, Shaykh Abdulaziz bin Abdullah al-Sheikh, on Thursday morning, 19 February 2009 in Riyadh).

${ }^{61}$ Kutty, supra note 2, p. 597.

${ }^{62}$ This is the opinion of Mālikĩ and some Shāfíi and Hanbali jurists and was stated to Imām Aḥmad Ibn Hanbal. See Al-Mawirdi, supra note 35, p. 382; Ad-Dirdir, Ash-Sharh As-Saghir, Vol. 2, p. 516; Ibn Qudamah, supra note 15, p. 95.

${ }^{63}$ M.H. Siddiqui, "Arbitration under the Sharīa wh with a case study of Saudi Arabia”, Transnational Dispute Management 2(January, 2005): 9. 
laws, in which there is great benefit to Islamic countries, especially those which attract international investments in oil and gas contracts, such as the GCC States. ${ }^{64}$ It should be noted here that the Great Mālikī Faqīh Ibn Mageshon holds a distinct opinion, as he sees that arbitration should become obligatory once the parties agree to arbitrate and even before the arbitrator starts to study the case. Some, such as Al-Samaan, state that this is a Mālikī opinion, which he reports to all Mālikī fiqh. ${ }^{65}$ In fact, it is an opinion of several but not all Mālikī scholars.

\subsection{Arbitration Award Enforcement and Mandatory Execution}

Whenever an arbitration award is issued, it becomes effective and applicable to the conflicting parties. No party has the right to retreat or withdraw, unless the award is contrary to the Islamic Sharíah. This is the opinion of the majority of jurists in the Hanafī, Mālikī, Shāfi ì and Hanbalīi ${ }^{-66}$ Schools. Their philosophy reasons that arbitration is a contract like any other contract, which means that it should be fulfilled and abided by as a solid principle of the Sharīah. On the other hand, some Shāfi i ${ }^{67}{ }^{67}$ jurists opine that an arbitration award is not obligatory unless all parties accept it. They reason that willingness is a vital condition to the formation of arbitration at the start, and it must remain so at the end. No doubt this opinion makes arbitration similar to conciliation, which is merely an attempt to reconcile the parties without having any obligatory effect. The rules of Sharīah law reject such a liquidation of the effectiveness of arbitration by exposing the entire arbitration process to a unilateral revocation, especially if good faith is not available from both or either party. ${ }^{68}$

It may be useful to accept the opinion of the majority of fuqa' $h \bar{a}$, because it gives an arbitration award dignity and strength as a judicial judgment. This coincides with modern requirements and the necessity to use arbitration to settle national and international commercial disputes. The majority

${ }^{64}$ See, e.g., Samir Salah, Commercial Arbitration in the Middle East (Oxford and Portland, OR: 2006) p. 41.

${ }_{65}$ Al-Samaan, supra note 59, p. 257.

${ }^{66}$ Al-Mawirdi, supra note 35, pp. 282-283; Al-Majallah, Article 1848; Ibn Farhoun, Tabsirat al-Hukkäm, Vol. 1, p. 44; Al-Ghazalī, Abū Hamid Muhammad, Al-Wasìt, Vol. 7 (Cairo: Dār al-Salam, 1997) p. 1; verified by Aḥmed Muhammad Ibrahim and Muhammad Moḥamed Tamer, p. 50.

${ }^{67}$ Ibid.

${ }^{68}$ See, in general, Nudrat Majeed "Good Faith and Due Process Lessons from the Sharīa ah”, Arbitration International 20(1) (2004): 104-109. 
of modern arbitration laws in the Islamic world adopt this opinion. On the other hand, evidence of the strength and effectiveness of an arbitration award in Sharî ah law and in which it has surpassed contemporary Western Law may be found in the fact that a majority of fuqa'hā from the Mālikī, Shāfi î, Hanbalī ${ }^{69}$ and some Hanafî scholars ${ }^{70}$ have agreed that, if an arbitrator has issued his award in accordance with the roots of Sharîah principles, the judge has no right to overrule the arbitrator's award. The award is effective and applicable even if it conflicts with the judge's opinion, and the judge should assume responsibility for implementation of the arbitrator's award. This position is based on the viewpoint that the arbitrator's award is correct and issued from a legal authority and that it is, therefore, irrevocable. Imām Abū Ḥanaf and several Hanafì scholars ${ }^{71}$ believe that the arbitration award can be revoked if the judge does not agree with the award. They contend that, while the arbitration award binds the disputing parties, it does not bind the judge, who has the right to accept or revoke the award. This opinion is in agreement with the majority of contemporary national arbitration laws, which allow an appeal of the arbitration award under certain conditions.

\subsection{Position of Women as Arbitrator, Witness or Party in Conciliation in the Shari ${ }^{-i}$ h}

Scholars of the four schools of fiqh disagree whether male gender is a requirement to be an arbitrator. ${ }^{72}$ Mālikīi, Shāfîi and Hanbalì jurists say that the male gender is a condition and that, as a result, a woman is not allowed to serve as an arbitrator. ${ }^{73}$ They support their opinion by saying that arbitration is similar to jurisdiction, and that since women are not allowed to handle jurisdiction, therefore, by qiyās (reasoning by analogy), they ought not to be involved in the arbitration process. In contrast, Hanafi

69 Ibid.; see also Siddiqui, supra note 63, p. 8.

${ }^{70}$ Ibn Nujaim, Zainuddin ibn Ibrahim, Al-Bahr ar-Ra’ iq, 2nd edn., Vol. 7 (Beirut: Dār al-Māerifah) p. 25.

71 Al-Sarakhsi, supra note 38, p. 111.

72 Al-Baji, Suleiman bin Khalaf, Al-Muntaqa Sharī ah al-Muwatta'Malìk, Vol. 4 (Cairo: Al-Sādah Printing, 1912) p. 113; Al-Asbahi, Malik bin Anas, Al-Mudawanah al-Kubrā, Vol. 5 (Beirut: Dār al-Sāder) p. 49; Al-Shirbini, supra note 20, p. 261; Ibn Abī al-Dam, Ibrahim Ibn Abdullah, Adab al-Qadī, The Iraqi Ministry of Endowments, Vol. 1, p. 431.

73 Ibn Mazah, Burhanuddin bin Muhammad, Al-Muhit al-Burhanī, Vol. 3, p. 398; AlSarakhsi, supra note 38, p. 111; Al-Mawirdi, supra note 35, p. 626; Ibn Qudamah, supra note 15, p. 39; Ibn Hazm, supra note 53, p. 490. 
and some Mālikī jurists, such as Ibn Jarir al-Tabarī and Ibn Hazm al-Andalusī, opine that women have the same rights as men to handle arbitration. ${ }^{74}$ Their position is based upon the view that the female gender does not prevent women from understanding and resolving issues in a dispute or arguments of opponents. Furthermore, Caliph Omar Ibn al-Khatțāb (d. 23H) appointed a woman (Al-Shifä) to serve as supervisor of the markets where she monitored the safety and accuracy of goods from fraud. In Islam, this process is called ( $h i s b a)$ and demonstrates that a woman is capable of handling the arbitration process. Perhaps this opinion is correct, since women are just as capable as men in acquiring soundness of mind, science and knowledge that will enable them to act in accordance with an arbitrator's function. Moreover, some women have surpassed men in the science of law and arbitration. Comparing arbitration to jurisdiction is inaccurate, because jurisdiction is a public authority and binding upon both the parties to the dispute as well as others. In contrast, an arbitrator's role is limited to the case to which s/he is assigned and, when $s /$ he issues the award, the judge will execute it. This opinion has been adopted by some contemporary scholars, such as Wahba al-Zuhaili ${ }^{75}$ and Abdul Karim Zeidan. ${ }^{76}$ The Sharí ah does not prevent a woman from playing an active role in mediation and conciliation. The Sharíah encourages civil society to adopt conciliation in general and is comprehensive for men and women without exception unless there is a clear statement from the Holy Qur'ān and the Sunnah identifying one gender rather than the other. However, in a wonderful step which confirmed the support of the Islamic Sharíah, women were given a role in the fields of arbitration and reconciliation and hired by the Saudi Minister of Justice to work as consultants in Saudi courts. This step will exert a positive impact in serving and helping the legal system and society. The new Saudi Minister of Justice, Muhammad El-Eesa, indicated the importance of introducing the Law of Arbitration and reconciliation as a major step in the right direction when he said: "We hope to introduce a law for the arbitration and reconciliation that will highlight, reduce and control the problems and family violence." 77

74 Ibid.

75 See Al-Zuhaili, Wahba, Al-Fiqh al-Islamī wa Adilatah (Islamic Jurisprudence and its Evidence), Vol. 6, p. 757.

76 Zeidan, Abdul Karim, Al-Mufasal fì Aḥkām al-Marä̀ wa l-Bait al-Muslim, Vol. 8, p. 421 .

77 Sabq electronic newsletter, issue dated 17/5/2009 (18-05-2009, 18.45 p.m.). http:// www.sabq.org/?action=shownews \&news=6739. 
From the author's point of view, if this were supported by a governmental organization, which would deal with arbitration and reconciliation cases, this organization would be responsible for enforcing this law and would play a positive role under the supervision of the legal system, the impact of which would become stronger, more positive and deeply rooted.

Arbitration procedures, including the testimony of female witnesses and the rules of evidence in front of a judge, are the same in arbitration. ${ }^{78} \mathrm{In}$ other words, a woman's testimony in front of an arbitrator is equal to half of a man's testimony ${ }^{79}$ under Sharíah law. ${ }^{80}$ Allahh states in the Qur'ān the wisdom of making man's testimony equal to the testimony of two women. Allāh says:

And call to witness, from among your men, two witnesses. And if two men be not (at hand) then a man and two women, of such as ye approve as witnesses, so that if one of the two erreth (through forgetfulness) the one of them will remind. ${ }^{81}$

This wisdom stated in the Qur ${ }^{2} \mathrm{n}^{82}$ is identical to the reasoning by schol$\operatorname{ars}^{83}$ as to why a man's testimony equals that of two women. According to Sharîa philosophy in all its legislation, a Muslim should abide by this even though he does not know the wisdom behind it. Allāh, who creates both men and women, knows the characteristics of each gender. Forgetfulness occurs equally in both men and women, although it might occur more frequently in women due to their passion. The wisdom behind the legislation may or may not be known. ${ }^{84}$ It may be only a mere metaphysical worship. A Muslim is not required to seek the wisdom hidden in some Sharīa ah legislation.

78 Majeed, supra note 68, p. 106.

79 It should be noted that Jewish law, secular laws in Switzerland and French law treats the testimonies of men and women differently. See Abdul Hamid El-Ahdab, Arbitration with the Arab Countries (The Hague: Kluwer Law International, 1999) p. 580.

80 Salah, supra note 64, p. 50.

81 Sürah Al-Baqara, Q2:282.

${ }^{82}$ It is noteworthy that the context of the verse indicates clearly that this position is only required when conducting business affairs. See Khaliq, Urfan "Beyond the veil?: An analysis of the provisions of the women's convention in the law as stipulated in Sharīah, Buffalo J. Int'l Law, 2(1) (1995): 27.

83 Al-Kasani, supra note 31, p. 7.

84 See, e.g., Mustafa Ahmad al-Zarqa' (1967), Al-Figh al-Islami fì Thawbihi l-Jadìd, alMadkhal al-Fiqh al-Islami [An Introduction to the New Version of the Principles of Islamic Jurisprudence] Vol. 1, pp. 50-59. 
What is required from male and female Muslims alike is the acceptance of Allāh's legislation, to recognize without any doubt and to believe deeply in his or her heart that this is for the good and benefit of mankind. ${ }^{85}$ Testimony in the Sharīah may present differing aspects, some of which may find a man's testimony totally unacceptable. In some situations, such as women's private affairs, which are difficult for men to understand, testimony is limited to women only. ${ }^{86}$

\subsection{Balanced Analysis}

We can justify the opinions that most Islamic scholars reached stemming from their understanding of the Holy verse (ayah) and from Prophet Muhammad's (PBUH) traditions. When the framework and regulations for the process of testimony was set, which Islam took into consideration, it was the era when the Qur'àn was being revealed and during Prophet Muhammad's (PBUH) message. During this era, a woman's status was far inferior to that of men. Some Arab tribes used to bury female babies alive and, in most tribes, women were deprived of any inheritance. Throughout history, women have experienced periods of fair treatment when they have enjoyed civil rights while during other eras they have been denied such rights. Such conditions also occurred simultaneously but in different societies and cultures with diverse policies. Moreover, male family members such as fathers, brothers, husbands or even sons could put pressure on women and influence her ability to give proper testimony. That is why Islam provided a fixed rule that should be applied regardless of the timeframe or social or political circumstances; i.e. a woman's testimony equals half that of a man's testimony regardless of whether she lives in a society which respects and grants her civil rights or treats her differently to the way men are treated. Generally, each legal system has a fixed law that will be applied regardless of the exceptions that may occur due to social or political change. What attracts our attention is that the differentiation between a man's or woman's testimony is not just dominated by Muslims as we may suspect at first glance. Jewish laws and some recent Western laws treat

${ }^{85}$ From an interview the author (Essam) held with Sheikh Abdulaziz bin Abdullah Alsheikh, General Muftī of the Kingdom of Saudi Arabia and Chairman of the Senior Scholars Commission, on Thursday, 19 February 2009.

${ }^{86}$ Ibn Rushd, supra note 14, p. 453; see also Abū Habib, Saadi, Mawsuwat al-Ijma fì $^{\circ}$ l-Fiqh al-Islami, Vol. 2(2101), p. 602. 
testimonies differently. ${ }^{87}$ If we revised the context of the Qurānic verse mentioned above, we might notice that it evolved to deal with the topic of documenting debts and salam contracts ${ }^{88}$ in particular. This is a clear way for contracting parties, as well as debtors and creditors, to document their deals in the form of contracts by first writing down their conditions before verifying their existence. Where the verse refers to the topic of testimony, it encourages contracting parties to seek the presence of a third party during the process of drawing up a contract. Such a third party (s/he) must be ready to bear the burden of testimony and be both capable and committed to understanding and memorizing the deal, which makes him/her able to testify to the correctness of the contract between parties if called in front of a judge. Actually, if we scrutinize carefully the context of the verse (ayah), we will find that it refers to capability and readiness to carry the burden of testimony; however, there is a difference between carrying the burden of testimony and actually testifying. If a woman forgets several details during her testimony, then she can ask another woman to help fill in the gaps. This second woman should also be willing to carry the burden of testimony in the same case. From the previous analysis, we can say that the stipulation (condition) that women carrying the burden of testimony must number two and not only one, may not mean that one woman's account would be rejected if she neither doubted the accuracy of her testimony nor failed to remember details when called upon to testify in front of a judge. The context of the verse is about carrying the burden of testimony, not the actual testimony. That is why contradictory opinions in jurisprudence occur between scholars on the extent to which a single

${ }^{87}$ See El-Ahdab, supra note 79, p. 580.

${ }^{88}$ A salam contract is one type of contract that has received much attention from Islamic laws. Scholars define this contract as being guaranteed where a current price is paid at the signing of the contract. This means that the contracting parties agree on the basis that one party will deliver specific merchandise at a specific date in the future, while he will receive its price at the time of signing the contract. It is important to mention that scholars have indicated that salam contracts are excluded from the general rules of business (sale). In other words, the salam contract contradicts the conditions that should be fulfilled in sales contracts that the merchandise has to be owned by the seller at the time of the deal or contract. Islamic law has allowed it, however, out of necessity in everyday life. Islamic law ignores the harm that might be caused if the seller does not have the merchandise (goods) in his hands at the time of the contract, in exchange for the benefits and gains for the people working with this type of contract. The order to make a contract simply states that one party will make or manufacture an article of merchandise such as clothes, pipes, specific products, etc. and that the buyer will receive the price at the time of contracting, while the seller will provide the product on the date set in the contract. 
woman's testimony can be considered valid regarding debts and all financial matters in general. Shayk Abd al-Rahman al-Saady, who is one of the greatest Saudi scholars in recent years (1376H $1956 \mathrm{CE})$, indicated that we can accept one woman's testimony in this case; his argument is that the wisdom in the above-mentioned verse can be achieved in one woman's testimony and does not require a man's testimony to validate it. ${ }^{89}$ If we look attentively at various Qur'ānic verses which mention financial testimony, we will find no discrimination on the basis of witness gender. ${ }^{90}$ In other words, whether male or female, witnesses should be treated equally. Acceptance of one woman's testimony as equal to one man's testimony was left to the judge's discretion; especially in cases where one woman's testimony is considered insufficient and unacceptable, many rights will be lost and harm done. This is supported by the fact that Muslim women have full control over their finances and wealth according to Islamic law, which demonstrates that women have full control over their commercial business without male interference. Therefore, in a conservative Muslim society, such as that in the Kingdom of Saudi Arabia, it may be difficult for women to ask men to bear witness of their dealings and carry the burden of testimony, especially in the case of business contracts in which all parties are women. Here we have reached a crossroad where we must reconsider the value of one-women testimonies. Should they be made equal to oneman testimonies in commercial business deals by diligently studying holy verses applicable in the current situation to achieve justice or right law (al-ijtihad), thus fulfilling needs and doing what is right in specific cases decided by a judge? Or should one-woman testimonies, which can lead to the loss of some rights for both men or women, be validated because witnesses might die leaving the court with one female witness or one female and one male witness. With regard to such a situation I. Nyazee says:

[t] he evidence of two women being equal to that of one man. This requirement is derived from a verse of Qur'ān, and is supported by the Sunnah... [I]t is suggested, however, that the scholars of this age may try to interpret the relevant verse of the Qurān as implying a recommendation rather than an obligation. It should be remembered again that rendering testimony is primarily a duty and not a right, through it leads to the protection of rights. ${ }^{91}$

${ }^{89}$ Abd al-Rahman Ben Nasser, Al-Saady, Taysìr al-Karìm al-Raḥman fì Tafsìr Kalām al-Manan, Vol. 1 (Al-Risalah Organization, 2000) p. 119.

${ }^{90}$ Justice Aftab, Hussain, Status of Women in Islam (Lahore: Law Publishing Company, 1987) p. 278 et seq.

${ }_{91}$ Nyazee, supra note 4, p. 121. 


\subsection{An Opinion in the Middle}

Some scholars, such as George Sayen, stand in the middle regarding identification of arbitration under the Sharíah. He believes that arbitration in Sharîah law first resembles conciliation and then develops until it becomes obligatory for both parties and must be implemented..$^{92}$ If we understand the nature of the role of conciliator, i.e. to encourage parties to reach a mutually acceptable solution to settle a dispute, ${ }^{93}$ then we can support this directive and adopt the opinion of some scholars regarding the non-obligatory nature of arbitration, especially during the early stages of the arbitration process. This doctrine is acknowledged and currently being put to practice in Western customs, where conciliation is applied as a first step and then arbitration is directly put to practice. ${ }^{94}$

\section{The Contemporary Concept of Arbitration in the Kingdom of Saudi Arabia}

Arbitration has been known in the Kingdom of Saudi Arabia since 1930, when the Commercial Court Act was established which organized arbitration into five Articles ${ }^{95}$ as a means to settle disputes. Although arbitration was dealt with in several Articles, at that time it was considered a wonderful pioneering incentive offering an alternative means for ending commercial disputes. ${ }^{96}$ In 1958, the Saudi Government lost its case against the American Oil Company (ARAMCO), ${ }^{97}$ which both parties had agreed to arbitrate, ${ }^{98}$ which was a powerful shock that affected the development of

92 Sayen, supra note 50, p. 932.

93 See Steven J. Burton "Combing conciliation with arbitration of international commercial disputes”, Int' Law \& Comp. Law Rev. 18 (1994-1995): 640-641.

94 Ibid., pp. 652-656.

95 Articles 493-497.

96 Although this law was issued early, it tackled important aspects of arbitration in a way that coincides with the achievements of modern arbitration doctrines. For example, the law included conditions which should be in arbitration, a method for appointing arbitrators, the duration of arbitration, and other important points.

97 Evidence of this is in Article 31 of the ARAMCO Concession Agreement of 1933 and Article 45 of the Getty Oil Concession Agreement (1949). See, e.g., Y. Al-Samaan, "Settlement of Foreign Investment Disputes by Means of Domestic Arbitration in Saudi Arabia", Arab Law Quart. (9(3) (1994): 218.

98 "The Government of Saudi Arabia v. Arabian American Oil Company (Aramco)", Int'l Law Rep. 27(1963): 117. 
arbitration in the Kingdom of Saudi Arabia. ${ }^{99}$ That loss may explain the current lack of knowledge in the Saudi commercial community regarding arbitration. ${ }^{100}$ In spite of that loss, the Saudi Government continued to develop arbitration through the issuance of an independent law for arbitration by Royal Decree in 1983. ${ }^{101}$ To institutionalize arbitration and make it more independent, the law gave the Saudi Chambers of Commerce power to create arbitration tribunals. This encouraged many foreign investors to state in their contracts that these Chambers would handle arbitration under the umbrella of the Saudi Arbitration Law (SAL).$^{102}$ It is

${ }^{99}$ See, e.g., K. Carlson, "International role of concession agreement", North Western Univ. Law Rev. (1958): 624.

100 The Saudi Government concluded an agreement with a Greek company in 1954, the term of which was 30 years, which involved granting the Greek company a privileged right to transport the oil and its derivatives from the Kingdom by sea. The Kingdom requested ARAMCO to respect the terms of this agreement, but ARAMCO alleged that the agreement, concluded in 1933, gave it an absolute right to choose the means of transporting the oil and its products, including transport on foreign oil vessels not belonging to ARAMCO. Unable to resolve the case amicably, the Kingdom agreed with the parties to opt for arbitration and signed an arbitration agreement on 23 February 1955. This began the Saudi Government's suffering with international arbitration, as the parties differed over which issues came under the scope of Saudi law and which did not. The Arbitration Tribunal held that the Saudi law was based upon the Hanbali School and that it is complemented, when necessary, by the general principles of international law and the prevailing custom in the oil industry. However, the tribunal declined to solicit the assistance of experts with broad knowledge and practice of Saudi law and the rules of the Sharíah and alleged that Saudi law as represented in the Hanbali jurisprudence was inadequate to handle the case and that it should be complemented by other legal sources. In actual fact, Hanbali jurisprudence is one of the broadest and most productive Islamic sects in dealing with transactions and commercial contracts. It is characterized by a wealth of general rules that govern contracts and concessions. This means that we need to revert to the specialists to ascertain the position of the Sharîah regarding the terms of the case, a step which regretfully the court refused to take. It is quite unfortunate that the Arbitration Tribunal's conduct in this case supports the opinion that international arbitration tribunals take arbitration as a means of imposing hegemony of the Western legal culture on different world nations without showing any respect for the national laws of those states.

${ }^{101}$ As time passed, the KSA took upon itself the development of its national laws, and so the author has re-drafted them in a manner that made it possible to achieve transparency and an easy reference as applicable laws derived from the Sharî́ah, and in general consistent with the system of international arbitration laws. This began a second renaissance of arbitration that has continued to grow and develop to the present day. In concurrence with the Kingdom's joining the World Trade Organization (WTO), most national laws pertaining to the judiciary, trade and investment have been updated.

102 Al-Juhaini, Aiydh (1985), "Explaining the new Saudi Arbitration Law", Chamber of Commerce Magazine, Riyadh, p. 22. 
clearly surprising that the Saudi judicial system created a supportive role for arbitration unlike the majority of other traditional laws, since the judicial system is suspicious, if not completely opposed, to arbitration. There are two reasons for this welcomed behaviour, the first of which is historical. Arbitration has been the way to resolve major conflicts in the Gulf region long before arbitration was accepted in modern countries. Arbitration was not limited to a specific area of law but assumed the role courts play in modern countries. Inherent to arbitration was the free will of conflicting parties to choose the arbitrator(s). Arbitration has usually been a powerful custom amongst Bedouin tribes and is a suitable system for social and political environments. The second reason is the positive view held by Islam towards arbitration. Both reasons provide a solid foundation for arbitration. It is therefore not surprising to learn that one of the first agreements endorsed by the Kingdom is the New York Convention (NYC). ${ }^{103}$ The following are the most distinctive points of the 1983 law:

(1) The law did not distinguish between commercial and other disputes, such as civil and real estate disputes.

(2) The law acknowledged agreements between parties to refer any future emerging disputes to arbitration. This is known as the arbitration clause. ${ }^{104}$

(3) The law granted the Saudi Judiciary authority and a prominent role in supervising arbitration. ${ }^{105}$

Notwithstanding these encouraging points, SAL is still considered outdated and no longer in keeping with the Kingdom's great leaps forward in the field of international commercial, especially after joining the WTO. ${ }^{106}$ There is an urgent need to issue a new law of arbitration or at least review the current Articles and amend them to suit contemporary commercial transactions, because the current law will soon have passed through three decades without having undergone any development or modernization.

103 Eid Rawach \& R. El-Rayes (2006), "The Law of Arbitration in Saudi Arabia, Reality and Perceptions”, Int'l Bus. Law J., Forum Europeen de la Communication, France, No. 5, pp. 617-618.

${ }_{104}$ M. Chaudhri \& M. Clodfelter "Commercial Arbitration in the Kingdom", Middle East Exec. Rep. 8(7) (1985): 9.

105 Sayen, supra note 50, p. 912.

106 World Trade Organization, 1995. 
The Kingdom's joining the NYC ${ }^{107}$ creates a sense of relief for foreign investors regarding their investments in the Kingdom, despite the fear by some that foreign awards will not be implemented in the Kingdom or that they may be revoked by the competent court. ${ }^{108}$ The process of executing foreign arbitration awards in the Board of Grievances also needs to be redrafted so that it will clearly define for foreign investors the concept of public policy and its limitations, because the Sharīah provides several interpretations according to the four Islamic Schools, and even within the same Hanbalī School.

\section{The Practical Difference between the Application both of sult and Arbitration in the Kingdom of Saudi Arabia}

In general, in the Kingdom of Saudi Arabia, arbitration is a combination of the Islamic concept derived from the Hanbali School and the contemporary concept known in the West. ${ }^{109}$ The principles established by the SAL provide that the obligations of the participating parties come under the authority of the judiciary that endorses arbitration documents to ensure their suitability for execution, and the obligatory nature of the award issued to the disputing parties. These principles demonstrate that arbitration in the Kingdom of Saudi Arabia is moving towards the modern concept of arbitration as an effective method of dispute resolution, as seen in the Western world. In fact, application of Saudi arbitration cannot be considered conciliation or sulh due to the nature of the obligation, which is clear and obvious, whether arbitration is national or international, in or outside the Kingdom. Saudi arbitration procedures are applicable to international agreements to ensure the application of foreign arbitration awards unless they conflict directly with the Sharîah. If it appears to the Saudi judiciary that the parties agree to settle their dispute through arbitration,

${ }^{107}$ New York Convention (NYC) on the Recognition and Enforcement of Foreign Arbitration Awards, 1958.

108 See, e.g., Kristin T. Roy (Note) "The New York Convention and Saudi Arabia: Can a Country Use the Public Policy Defense to Refuse Enforcement of Non-Domestic Arbitral Awards", Fordham Int'l Law J. 18(1995): 921.

109 See, e.g., Nayla Comair-Obeid, The Law of Business Contracts in the Arab Middle East: A Theoretical and Practical Comparative Analysis (with Particular Reference to Modern Legislation) (The Hague: Kluwer Law International, 1996) p. 119. 
whether in an independent agreement or as a clause in the contract, then the Saudi judiciary will refer the parties directly to arbitration.

Award of the Board of Grievances states that:

In accordance with the contract signed between the two parties, they agreed to refer this dispute to arbitration and each of them chose an arbitrator, and the third arbitrator had been selected as stated in the signed arbitration document. Accordingly, the case has been transferred to the Arbitration Commission. ${ }^{110}$

From this practical application of arbitration, we find that the Saudi judiciary, whether in general or summary courts, applies conciliation, reconciliatory sulh rather than issue a certain award not depending upon amicable ways to settle disputes. This application applies to many types of cases: marriage, civil or commercial. In fact, marriage arbitration is conciliation because it is based upon the effort of the arbitrator to reunite the family, to bridge the gaps, and to bring forward viewpoints of the spouses to prevent divorce. ${ }^{11}$ An award from the General Court at Riyadh includes that an arbitration commission is established, meets with the spouses, and issues a resolution addressed to the judge that includes the following:

\footnotetext{
A meeting was held with the parties. We tried several times with the wife to return to the matrimonial home for the mercy of her children, but she insisted on divorce presenting her initiative to hand over the above-mentioned financial compensation for the husband to divorce. Lately, the husband agreed upon her initiative with a condition that she gives up custody of her children in his favour, and the wife agreed. ${ }^{112}$
}

On this basis, the wife hands over money to her husband in front of the judge. Accordingly, the judge passes judgment establishing separation between the spouses following the husband's utterance of divorce before the honourable judicial panel.

Regarding sulh, the Saudi judiciary expands the circle for offering sulh to the parties to prevent judgment without reconciliation between them. ${ }^{113}$ The judiciary manifests a desire to calm the parties down and occasionally to take into account the financial circumstances that may hinder the defen-

\footnotetext{
110 Judgment No. 18 /D/ Commercial/1/ in 1416H in Case No. 1929/1/G in 1413 in case Al-Babtain for Commerce and Middle East System v. Software Middle East GMBH, p. 34.

${ }^{111}$ See Frank E. Vogel, Islamic Law and Legal System, Studies of Saudi Arabia (Leiden: Brill Academic Publishers, 2000) p. 141.

112 Judgment issued from the General Court at Riyadh in November, 2004.

${ }^{113}$ See, e.g., Vogel, supra note 111, p. 120.
} 
dant's payment of debt or the amount claimed, which could cause the defendant to end up in prison. The judge considers these points and persuades the plaintiff to waive some of the money and reconciles between the parties before the judge issues his award based upon the reconciliation. Application of reconciliation in front of a judge comes in different forms, depending upon the status of the case. We can identify major features for these types of reconciliation which frequently occur in Saudi courts:

(1) The amount claimed by the plaintiff is not identified. As illustration, assume that the plaintiff demanded in court that the defendant repair the damage caused by the latter to a property or the body of the plaintiff. In normal cases, the judge will assign experts in the specific field to assess compensation. However, in most cases, the judge offers reconciliation to the parties with his desire to resolve the issue as soon as possible so that the case will not be appealed. ${ }^{114}$ In this type of case in particular, a fiqh issue (obstacle) exists because Mālikī jurists, along with Imām al-Shāfi ī, require that, for reconciliation to be valid, it must be identified as a sales contract, which requires in every case that the price be known by both parties.

Imām al-Shāfí ī stated: "Reconciliation on an unidentified thing is not valid, because Reconciliation is a sale, and a sale on an unidentified thing is not valid." 115

In fact, in this type of compensation, in which the plaintiff's claim is for an unknown value, the Saudi judiciary seems to adopt the view of Hanafì and Hanbali scholars, who approve the reconciliation even if the amount of compensation claimed is unidentified. Their philosophy is that reconciliation is similar to exoneration in that both parties have the right to waive the whole claim. They support their opinion by the idea that, if reconciliation is valid when the parties know the claimed amount, then reconciliation is no less valid if the claimed amount is unknown. Perhaps the strongest evidence in favour of their opinion rather than that mentioned in the Mālikī opinion is that of Prophet Muhammad who ordered two people who had a dispute over the value of a very old inheritance to come to him to resolve their dispute. Although the Prophet ordered them to reconcile and share the inheritance, each expressed forgiveness to the

${ }^{114}$ Judgment issued from Summary Court at Riyadh, No. 352/7 in 1429/8/1H (2008).

${ }^{115}$ Ibn Qudamah, supra note 15, p. 490. 
other before Allāh for any shortage or damage occurring during the sharing process. ${ }^{116}$

(2) The second type, which is common among the Saudi judicial rank, is the same classical type of reconciliatory sulh contract in Sharīah law, where the plaintiff has to give up willingly part of his claim in order to solve the case quickly and amicably. The same justifications for the first type of reconciliation apply here, i.e. that the judge desires to end the dispute quickly before it becomes subject to appeal. ${ }^{117}$ The judge's desire to close each case quickly and to avoid the issuance of a final award may, however, force either or both parties to take the case to the Court of Appeals and perhaps on to the Supreme Court. All of this forces judges to offer reconciliation to the disputing parties in every case to avoid a backlog of cases being appealed. This attitude must be reviewed and not be permitted to continue in current practice. Justice requires that the judge enter judgment in favour of the party who has, by proper evidence, proven his right to prevail. The judge must not press either party to waive any right for the sake of reconciliation. Parties should be free to pursue an alternative method of resolving their dispute or to press their case to conclusion at trial without undue pressure from the judge. The extent to which judges apply pressure upon parties to settle must be explored through a specialized comprehensive statistical study. This point is left for Saudi law researchers, especially those who wish to complete their higher education at a Ph.D. stage. It is an important issue, and understanding its dimensions may create positive proposals for decision-makers, who may reflect in review and develop a new judicial attitude that will achieve desired justice.

\section{Conclusion}

We can summarize what has been discussed above as follows:

(1) Arbitration has always been a means of settling disputes, whether between individuals or between tribes. Islam approves, organizes

116 Al-Shawkani, Muhammad ibn Alī (2002), Nail al-Awtār min Aḥadìth Sayid al-Akhyār, Vol. 5, p. 253.

117 Judgment Issued from Summary Court at Riyadh, No. 111/7 in 1429/8/1 (2008), Judgment No. $109 / 7$ in 1429/8/1 (2008) \& Judgment No. $110 / 7$ in 1429/8/1 H (2008). 
and promotes arbitration from non-obligatory to a contract binding upon all parties with the power of a judicial judgment.

(2) There has been confusion between the linguistic and legal concepts of sulh. Some consider arbitration under Sharīah law as nothing more than conciliation, because here arbitration is not obligatory, even after issuance of an award and, therefore, resembles conciliation. Confusion about arbitration in cases between spouses and all other types of cases contributes to this concept. The first concept (linguistic) resembles conciliation, while the second is similar to the contemporary Western concept of arbitration. Some believe that arbitration under Sharíah law is conciliation gradually upgraded to obligatory arbitration whenever award is issued. This is a considerable opinion.

(3) Sharīah law offers several interpretations of arbitration and its obligatory nature in general. However, a majority of the scholars in the four schools agree that an arbitration award is binding upon all parties whether it offers them satisfaction or not. Contemporary Islamic fiqh adopts Mālikī as well as several Shāfíì and Hanbalī opinions in asserting that continuation in arbitration is binding upon both parties directly after commencement of the arbitration proceedings. The fact that no party has the right to retreat complies with the Sharīah principle, which always assures respect for contracts and fulfilments.

(4) The majority of scholars from the four schools agree that a party may dismiss the arbitrator before commencement of arbitration proceedings. In fact, this should not be understood as a way to retreat before commencement of arbitration. Parties who agree to participate in arbitration must be bound by that agreement to fulfil their commitment. There is a difference between the right to dismiss an arbitrator and continue with a different arbitrator and the termination of the entire arbitration process.

(5) We can summarize the differences between arbitration and reconciliatory sulh according to the Sharīah as follows:

I. Arbitration results in a judicial award, while sulh results in a contract agreement between disputing parties. There is a difference between the judicial award and consensual contract.

II. In sulh, one or both of the parties waives rights, in contrast to arbitration in which no rights are waived.

III. Sulh is an obligatory contract binding upon both parties, while, in the opinion of the majority of scholars, arbitration is not obligatory until the issuance of an award. 
IV. Sulh takes place after a dispute has occurred and the plaintiff has asserted his/her claim against the defendant, while arbitration may be agreed upon prior to, during, and after the dispute.

V. Sulh has multiple forms under Sharīa ah law, depending upon the condition of the defendant, while there is only one type of arbitration regardless of the dispute.

VI. Jurists $\left(f u q a^{\prime} h \bar{a}\right)$ stipulate that the arbitrator must satisfy certain conditions, such as having the male gender, being Muslim and sanity, none of which are stipulated for sult parties.

VII. In arbitration, a third party serves as the arbitrator(s) and manages the arbitration process, while in reconciliation the presence of a third party is not required.

Sometimes, it is possible for a third party to interfere as mediator; the judge may offer both parties reconciliation to assist in solving the issue amicably.

(6) There is a difference between the application of arbitration and reconciliatory sulh in the Kingdom of Saudi Arabia. Arbitration is governed by a special law, which combines the Islamic and Western concepts of arbitration. While reconciliatory sulh is often encouraged by judges and practiced in the corridors of the courts, it is useful to establish a Board in the Ministry of Justice that deals with reconciliation to supervise, monitor and document any reconciliation between the parties. This step will enhance the status of reconciliation and reduce the judiciary's role to notarization. Moreover, the culture of reconciliation would prevail in the society as an alternative means to resolve disputes. ${ }^{118}$

${ }^{118}$ A few days after writing the draft of this article, the Chief Judge of the Summary Court in Riyadh, Dr. Salah Alsheikh, announced that the Riyadh courts have established divisions for Arbitration, Reconciliation and Mediation where they will work on family, traffic and judicial cases. This recommendation was confirmed in public, which shows how important and how badly needed it was. It is a great step in supporting the process of Arbitration, Reconciliation and Mediation by organizations in a civil society represented by the legal system. See the newspaper Al-Riyadh, Issue 14905, 15 April 2009 (16-05-2009, 15:45 p.m.), http://www.alriyadh.com/2009/04/15/article42252.html. 